\title{
マインドフルネス特性が道德判断における 嫌悪感の自動的な転移に及ぼす効果
}

\author{
佐藤 德 富山大学 杉浦 義典 広島大学
}

\section{Dispositional mindfulness modulates automatic transference of disgust into moral judgment}

\author{
Atsushi Sato (University of Toyama) and Yoshinori Sugiura (Hiroshima University)
}

\begin{abstract}
Previous studies showed that incidental feelings of disgust could make moral judgments more severe. In the present study, we investigated whether individual differences in mindfulness modulated automatic transference of disgust into moral judgment. Undergraduates were divided into high- and low-mindfulness groups based on the mean score on each subscale of the Five Facet Mindfulness Questionnaire (FFMQ). Participants were asked to write about a disgusting experience or an emotionally neutral experience, and then to evaluate moral (impersonal vs. high-conflict personal) and non-moral scenarios. The results showed that the disgust induction made moral judgments more severe for the low "acting with awareness" participants, whereas it did not influence the moral judgments of the high "acting with awareness" participants irrespective of type of moral dilemma. The other facets of the FFMQ did not modulate the effect of disgust on moral judgment. These findings suggest that being present prevents automatic transference of disgust into moral judgment even when prepotent emotions elicited by the thought of killing one person to save several others and utilitarian reasoning conflict.
\end{abstract}

Key words: mindfulness, moral judgment, disgust, automaticity, acting with awareness.

The Japanese Journal of Psychology

2014, Vol. 84, No. 6, pp. 605-611

感情が後の無関連な判断に影響を与えることは, 人 生満足度, リスク評価, 人物評価, 政治的判断など, 様々 な指標を用いて検討され, そのメカニズムについても, 感情ネットワーク説（感情がリンクで繫がった概念や 行動を活性化させる), 情報としての感情説（感情を 対象を評価する際の情報として用いる）など様々な仮 説が提出されてきた (Clore \& Huntsinger, 2007)。近年 では, 道徳判断のような, これまでは高次の理性的推 論によるとされてきた判断も (Kohlberg, 1969), 感情 の影響を強く受けると考えられるようになってきた。 その代表的な例が, Haidt (2001) による道徳判断の社 会的直観モデルである。彼によると, 道徳判断は, Kohlberg が言うような道德的な推論によってではな く，速やかに生じる自動的で感情的な直観によってな されるという。たとえば, 履歴書に虚偽情報を入れた

Correspondence concerning this article should be sent to: Atsushi Sato, Faculty of Human Development, University of Toyama, Gofuku, Toyama 930-0887, Japan（e-mail: a_sato@edu.u-toyama.ac.jp）
というような話を聞くと，それについてよいとか悪い とかいう評価的な感情が, 関連情報を探索し, 証拠を 重み付け, 結論を導き出すといった意識的な推論のプ ロセスを経ずにたちまち意識に現れ，そうした感情が 自動的に道德判断を方向づける。確かに, 我々はより 統制的な道徳推論を行うこともある。しかし，それは 最初の自動的な評価的処理の後であり, たいていは最 初の直観を支持する証拠を探し，事後的に直観を正当 化するだけになりがちだという。

感情的な直観が道徳判断を自動的に方向づけるとす る Haidt（2001）のモデルからは, 判断と無関連に生 じた感情も道德判断に自動的に波及すると予想される が，これは道德判断が恣意的に導入された吐き気やむ かつきといった生理的な嫌悪感の影響を受けるとする 近年の研究によって支持されている (Eskine, Kacinik, \& Prinz, 2011; Schnall, Haidt, Clore, \& Jordan, 2008; Wheatley \& Haidt, 2005)。たとえば, 苦い飲み物を口 にした後だと，水や甘い飲久物を口にしたときと比べ て, 道德判断が有意に厳しくなる (Eskine et al., 2011)。 
逆に，日本語でも“水に流す”というが，嫌悪導入後 に手を洗うと, 洗わない場合に比べて道德判断はより 甘くなるという（Schnall, Benton, \& Harvey, 2008）。特 に，自身のわずかな身体感覚の変化に気づきやすい人 でこうした生理的な嫌悪感の無関連な道徳判断への自 動的な転移が起こりやすく, また, 道德判断が厳しく なるという結果は悲しみでは見られず，ネガティブ感 情全般の効果ではないという（Schnall, Haidt et al., 2008）。すべての利用できる情報を加味したうえでの 理性的な判断は現実には困難であり, 多くの場合, 感 情に駆動された判断は有用であり，適応的でさえある (Damasio, 1994)。しかし，それは望ま姞果を招く 場合もある。たとえば，異性愛者に嫌悪導入すると同 性愛者に対してネガティブな態度を示すようになるこ とが報告されている（Inbar, Pizarro, \& Bloom, 2012）。 こうした例のように，恣意的な生理的嫌悪感の導入に よって自覚さえ伴わずに特定の社会集団に対する道德 的な嫌悪感が増し, 結果として特定集団の差別や排除 が助長されるとすれば，それは決して望ましいことで はない。

問題はどのようにこうした否定的な結果を回避する かである。思考抑制や差別しないようにするなどの意 識的な制御は，認知負荷が高い場合や自己制御に用い る資源が枯渴した場合には，皮肉にも意図したものと 逆の効果をもたらすことが知られている（DeWall, Baumeister, Stillman, \& Gailliot, 2007; Macrae, Bodenhausen, Milne, \& Jetten, 1994)。こうした方略と 対照的なのが, マインドフルネスである。マインドフ ルネスとは，特別の方法で注意を向けること，すなわ ち, 意図的に, 今この瞬間に, 価值判断をすることな しに注意を向けることと定義される（Kabat-Zinn, 1990)。マインドフルネスでは，ある対象をネガティ ブに評価して抑制するなどといった意識的な制御は行 わない。価值評価せずに，たとえそれが嫌悪感であっ ても，ただ，今起こっていることをありのままに見守 るのみである。しかし, そうであるがゆえに, マイン ドフルネスは, 認知負荷が高い場合であっても感情の 無関連な判断への自動的な転移を防ぎうる可能性があ る。

本研究の目的は, 既存の五つのマインドフルネス尺 度をジョイント因子分析することで作成された Five Facet Mindfulness Questionnaire (FFMQ: Baer, Smith, Hopkins, Krietemeyer, \& Toney, 2006）の日本語版 (Sugiura, Sato, Ito, \& Murakami, 2012) を使用し, 抽出 された, 観察（音や匂い, 身体感覚など, 外的・内的 な様々な刺激に注意を払い観察すること)，気づきの 伴う行為（その瞬間瞬間で起こっていることや自分の していることに気づき注意を持続すること), 判断し ないこと（そのように考えるべきではないなど，自分 の体験に批判的・評価的に接しないこと), 描写（自
分の体験を適切な言葉で表現すること), 反応しない こと（自分の思考や感情にとらわれて過剩に反応せず 距離を置いてそれらを受け止めること）の五つの側面 のうち, どの側面が生理的嫌悪感の道徳判断への自動 的転移を防ぎうるかを検討することである。

道德判断課題は, 5 人の鉄道作業員を救うために 1 人の鉄道作業員の命を犠牲にするといった倫理的なジ レンマ課題を用いる。こうした課題を用いた Greene ら (Greene, Nystrom, Engell, Darley, \& Cohen, 2004; Greene, Sommerville, Nystrom, Darley, \& Cohen, 2001) は，道徳判断の二過程理論を提起している。それによ ると, 数人を救うために 1 人の人間を殺すという考え は，優勢なネガティブな感情反応を引き起こし，その ようなことは道德的に許されないと否定的な意見を駆 り立てる。と同時に, 人は功利主義的な道徳推論も行 う。非個人的ジレンマ場面のように特に優勢な感情反 応がなければ，そのまま最終的に，ょり多くの人間を 助けるという功利主義的な判断がなされる。しかし, 個人的なジレンマ場面のように, 優勢な感情反応と功 利主義的な推論が競合する場合もある。こうした場合 は, 優勢な感情反応に打ち克つため, 付加的な認知的 統制处理が必要となるという。この二過程理論は, 個 人的なジレンマ場面ほど感情的な処理に関わる部位が 活動すること，また，個人的な場面でもより葛藤の大 きい場面ほど，競合の検出に関わる前部帯状皮質や認 知的統制処理に関わる前頭前野背外側部が活動するこ と, さらには, 認知的負荷によって個人的ジレンマ場 面でも葛藤が大きい場合に功利主義的な判断に要する 反応時間が選択的に増加することなどによって支持さ れている (Greene et al., 2001, 2004; Greene, Morelli, Lowenberg, Nystrom, \& Cohen, 2008)。

本研究では道徳判断課題に用いる場面として, 数人 を救うために 1 人の人間を殺すという行為に対し，感 情的な抵抗のより少ない非個人的ジレンマ場面と, 特 に抵抗の大きい個人的ジレンマ場面を用いる。それに よって, 感情的抵抗の少ない場面のみならず, より統 制的処理が必要とされる個人的ジレンマ場面でも， マ インドフルネス傾向が生理的な嫌悪感による道徳判断 への影響を緩和するかどうかを検討する。

\section{方法}

\section{実験参加者}

19 歳から 23 歳までの 92 名の大学生（女性 51 名, 男性 41 名）が実験に参加した。実験参加者の平均年 齢は 19.96 歳 $(S D=.95)$ であった。すべての実験参 加者に対して, 実験の手続きの概要について説明し, 実験への参加は本人の自由であり, 参加しない場合も 途中で辞退する場合も何の不利益も生じないことを説 明した後，書面によりインフォームドコンセントを得 


\section{た。実験の真の目的に関しては, 実験終了後に説明し た。}

\section{材 料}

FFMQ 日本語版（Sugiura et al., 2012） 本尺度は, 序論で述べた 5 因子からなる FFMQ の日本語版であ る。計39項目について“1. まったくあてはまらない(非 常にまれにしかあてはまらない)”から“5.いつもあ てはまる(非常にしばしばあてはまる)”までの 5 件 法にて回答を求め, 下位尺度毎に合計点を算出した。 合計点は各次元の傾向が高くなるほど高得点になる。

道徳判断課題 Greene et al. (2001) などの先行研 究から, 道徳判断に関わる六つの場面, 道徳判断に関 わらない三つの場面を選択し，翻訳して使用した。六 つの道徳判断場面の内, 三つは非個人的なジレンマ場 面, 残りの三つは特に葛藤の大きい個人的なジレンマ 場面とした。道徳判断に関わらない場面の例は, ブラ ウニーを作ろうと決心したが, レシピに書いてあるク ルミが好きではなく, クルミの代わりに自分の好きな マカダミアナッツを入れる，といった場面であった。 非個人的なジレンマ場面の例は, 運転しているトロッ コが暴走してしまい，このまま進むと 5 人の鉄道作業 員を轢き殺してしまうが，切り替え装置を押せば， 5 人の命を助けることができるが, 切り替えた先にいる 1 人の鉄道作業員を犠牲にしてしまうといった場面で あった。また，個人的なジレンマ場面の例は，このま ま進むと暴走するトロッコが 5 人の鉄道作業員を轢き 殺してしまうが，たまたま自分の近くにいる大柄の見 知ら男性を自分が歩道橋から突き落とせば， 5 人が 䡦き殺される前にトロッコを止めることができると いった場面であった。これらの場面はランダム順で A4 の用紙に印刷され，実験参加者はそれぞれの場面 を読んで, 嫌悪感の道徳判断への影響を調べた先行研 究と同様に (Schnall, Haidt et al., 2008), 5 人の鉄道作 業員の命を救うために 1 人を犠牲にするなどの場面に 記された行為をどの程度悪いと感じるかを, “0. 全く 問題ない”から“9. 非常に悪い”までの 10 件法で回 答するように求められた。

気分評定 嫌悪気分が適切に導入されたかを確認す るため, 実験の開始時と終了時に, “リラックスした” “怒った”“幸せな”“悲しい”“恐れた”“ゆううつな” “嫌悪感を覚えた”の 7 項目について, 現在の気分を“1. 全く感じない”から“7. 非常に強く感じる”までの 7 件法で回答させた。項目の選定は Schnall, Haidt et al. （2008）に基づいた。なお，気分導入直後に気分評定 を行えば，気分変化の原因が導入手続きに正しく帰属 され, 気分の判断への転移が生じなくなる可能性があ り (Schwarz \& Clore, 1983), 本研究では, 気分導入直 後ではなく，実験終了時に気分評定を行った。

\section{手続き}

実験参加者は最大 4 名の小グループで実験室に入室 し，それぞれがカーテンで仕切られた机に着席した。 着席後, 実験参加者は, まず, FFMQ 日本語版に回答 し，その後，ベースラインの気分評定を行った。その 後, 嫌悪気分導入群では, 自分に起こった, 吐き気を 催す, 胸がムカムカするなどの生理的な嫌悪感を覚え させるような何かを見たり触れたりした体験を思い出 し, 指定の用紙にできるだけ詳細に書くように求めた。 その際, 生理的な嫌悪感を覚えさせる体験の例として, 吐瀉物や排泄物で污れた污臭のする不潔なトイレの利 用，腐って嫌な臭いのする食べ物などを挙げた。統制 群では, 清潔でも不潔でもない大教室での講義授業の 様子を思い出し, 指定の用紙にできるだけ詳細に書く ように求めた。導入は 6 分間とし, どの程度詳細に思 い出せたかを, “1. 全然思い出せなかった”から“7 極めて詳細に思い出せた”の 7 件法で評定させた。そ の後, 一旦実験の終了を告げ, 別の実験者が引き続き 別の調查を行うとの名目で道徳判断課題を実施した。 実験者の交替は, 気分導入までの実験と道德判断課題 がまったく別の実験であり，両者は無関連であること を実験参加者に信じさせるために行った。道德判断終 了後, 再度気分評定を求め, 気分導入と道徳判断課題 との関係に気づいたかどうかを口頭で尋ねたうえで, 実験の真の目的を説明した。その際, 嫌悪気分導入群 の参加者に対しては，ポジティブ気分の導入を行った うえで再度気分評定を求め, 気分が回復したことを確 認したうえで実験を終了した。嫌悪気分導入群と統制 群の割り当てはランダムに行い, 参加者が記入した回 答用紙は参加者自身が前半部・後半部それぞれ異なる 封筒に入れて厳封することで, 回答の匿名性を守った。 データの照合は各用紙に記された ID 番号によって 行った。

\section{結果}

気分導入と道德判断課題との関係に気づいた者 2 名, 欠損值のあった者 3 名, 気分導入の際に詳細に出 来事を想起できなかった者（3 点以下） 11 名の計 14 名分 (2 名は複数に該当) を除いた 78 名分 (女性 46 名, 男性 32 名）のデータについて分析を実施した。

気分導入チェック 目的通り嫌悪気分が導入された かを確認するため, マインドフルネスの各下位尺度得 点の平均值により高低群を分け, 実験終了時の嫌悪感 評定值を従属変数, 対象となる下位尺度の高低と気分 導入条件を独立変数, ベースライン時の嫌悪得点, 検 討対象以外のマインドフルネス下位尺度得点を共変量 とする, 2 要因の共分散分析を行った。各条件の人数 は Table 1 の通りである。まず，気づきを伴う行為の 高低を独立変数とした分析を行ったところ，気分導入 
Table 1

Number of participants assigned to each condition

\begin{tabular}{lcccc}
\hline $\begin{array}{l}\text { Mood Induction } \\
\text { FFMQ Substate }\end{array}$ & \multicolumn{2}{c}{$\begin{array}{c}\text { Control } \\
\text { High }\end{array}$} & $\begin{array}{c}\text { Disgust } \\
\text { Low }\end{array}$ & $\begin{array}{c}\text { Control } \\
\text { Disgust }\end{array}$ \\
\hline Act with aware & 21 & 20 & 15 & 22 \\
Nonjudge & 12 & 23 & 24 & 19 \\
Nonreactivity & 19 & 15 & 17 & 27 \\
Describe & 18 & 24 & 18 & 18 \\
Observe & 18 & 16 & 18 & 26 \\
\hline
\end{tabular}

条件の主効果 $\left(F(1,69)=6.26, p<.05, \eta_{\mathrm{p}}{ }^{2}=.086\right)$ と 気づきを伴う行為の主効果 $(F(1,69)=12.73, p<.01$, $\left.\eta_{\mathrm{p}}{ }^{2}=.156\right)$ が有意であった。単純主効果の検定の結 果 (Bonferroni, $p<.05)$, 嫌悪条件の嫌悪得点 $(M$ $=4.12, S E M=.24)$ は有意に統制条件 $(M=3.20$, $S E M=.26)$ より高く,また,気づきを伴う行為低群 $(\mathrm{M}$ $=4.38, S E M=.28)$ は高群 $(M=2.95, S E M=.25)$ より嫌悪得点が高かった。しかし，両者の交互作用は 有意ではなく $(F(1,69)=0.05, n s)$, 高群でも嫌悪導 入により嫌悪感が導入されていた。同様に, 他の各マ インドフルネス次元についても検討を行ったが，描写 の主効果 $\left(F(1,69)=5.62, p<.05, \eta_{\mathrm{p}}{ }^{2}=.075\right)$, 判断 しないことの主効果 $\left(F(1,69)=3.19, p=.079, \eta_{\mathrm{p}}{ }^{2}\right.$ $=.044)$, 判断しないことと導入条件の交互作用 $(F$ $\left.(1,69)=2.92, p=.092, \eta_{\mathrm{p}}{ }^{2}=.041\right)$ を除いて, いずれ も導入条件の主効果のみが有意であり, 各マインドフ ルネス次元の主効果 $\left(F_{\mathrm{S}}<1.03\right)$ と交互作用 $\left(F_{\mathrm{S}}<.42\right)$ は有意ではなかった。導入条件の主効果は, いずれも 嫌悪条件の嫌悪得点が統制条件より有意に高いという ものであった。描写の主効果は, 高群の嫌悪得点 $(M$ $=4.09, S E M=.28)$ が低群 $(M=3.08, S E M=.30)$ より有意に高いことによるものだった。また, 判断し ないこと低群の嫌悪得点 $(M=3.94, S E M=.24)$ が 高群 $(M=3.24, S E M=.30)$ より高い傾向があった。 判断しないことと導入条件の交互作用は, 低群では嫌 悪導入により嫌悪得点が有意に上昇するが（統制 $M$ $=3.11, S E M=.33$ vs. 嫌悪 $M=4.78, S E M=.34)$, 高 群では有意な得点の上昇は見られないというもので あった（統制 $M=3.06, S E M=.48$ vs. 嫌悪 $M=3.42$, $S E M=.38)$ 。他の感情についても同様な分析を行っ たが，すべてのマインドフルネス次元において嫌悪導 入条件で統制条件より幸福得点が低下すること（4.11 $\left.<F_{\mathrm{S}}<6.45\right)$, 気づきを伴う行為高群 $(M=2.96$, $S E M=.17)$ は低群 $(M=2.25, S E M=.19)$ より有意 に幸福得点が高いこと $\left(F(1,69)=6.88, p<.05, \eta_{\mathrm{p}}{ }^{2}\right.$ $=.091)$ 以外はいずれの感情得点においても, 有意な 導入条件の主効果も各マインドフルネス次元の主効果 も両者の交互作用も見られなかった。

道徳に関わらない判断 各下位尺度得点の平均值に
より各マインドフルネス次元の高低群を分け，道徳判 断に関わらない 3 場面の合計值を従属変数, 検討対象 次元の高低と気分導入条件を独立変数, 検討対象以外 のマインドフルネス下位尺度得点を共変量とする，2 要因の共分散分析を行った。その結果, いずれのマイ ンドフルネス次元に拈いても, 有意な, マインドフル 六次元の主効果 $\left(F_{\mathrm{S}}<.75\right)$, 気分導入条件の主効 果 $\left(F_{\mathrm{S}}<.83\right)$, 両者の交互作用 $\left(F_{\mathrm{S}}<2.34\right)$ が見ら れなかった。

非個人的道徳判断 非個人的なジレンマ場面につい ても同様の分析を行った。その結果，気づきを伴う行 為以外の次元においては, 気分導入条件の主効果のみ が有意であり $\left(10.95<F_{\mathrm{S}}<14.67\right)$, マインドフルネ ス次元の有意な主効果 $\left(F_{\mathrm{S}}<.75\right)$ もマインドフルネ 又次元と気分導入条件の有意な交互作用 $\left(F_{\mathrm{S}}<1.29\right)$ も見られなかった。気分導入条件の主効果は, 嫌悪導 入条件において道德判断が有意に厳しくなるというも のであった。他方，気づきを伴う行為次元においての みは, 気分導入条件の有意な主効果のみならず $(F$ $\left.(1,70)=14.41, p<.01, \eta_{\mathrm{p}}{ }^{2}=.171\right)$, 気づきを伴う行 為と気分導入条件の有意な交互作用が見られた $(F$ $\left.(1,70)=4.57, p<.05, \eta_{\mathrm{p}}{ }^{2}=.061\right)$ 。気分導入条件の主 効果は, 他のマインドフルネス次元と同様に, 嫌悪導 入条件 $(M=19.33, S E M=.84)$ において統制条件 $(M$ $=14.49, S E M=.93)$ よりも有意に道德判断が厳しく なるというものだった。しかし，ここで重要なのは交 互作用である。Table 2 に見るように, 交互作用は, 気づきを伴う行為低群では, 嫌悪導入によって有意に 統制条件より道徳判断が厳しくなるのに対し（統制 $M=13.15, S E M=1.52$ vs. 嫌悪 $M=20.69, S E M=$ 1.16), 高群では両導入条件の間に有意な差が見られ ないことによっていた（統制 $M=15.83, S E M=1.21$ vs. 嫌悪 $M=17.96, S E M=1.23)$ 。気づきを伴う行為 の主効果は有意ではなかった $(F(1,70)=.01, n s)$ 。

個人的道徳判断 個人的なジレンマ場面についても 同様の分析を行った結果, 非個人的道徳判断と同様の 結果が得られた。すなわち, 気づきを伴う行為以外の 次元においては, 気分導入条件の主効果のみが有意で あり $\left(5.13<F_{\mathrm{S}}<7.88\right)$ ， マインドフルネス次元の有 意な主効果 $\left(F_{\mathrm{S}}<2.46\right)$ もマインドフルネス次元と 気分導入条件の有意な交互作用 $\left(F_{\mathrm{S}}<.54\right)$ も見られ なかった。気分導入条件の主効果は, 嫌悪導入条件に おいて道徳判断が有意に厳しくなるというものであっ た。他方, 気づきを伴う行為次元においてのみは, 気 分導入条件の有意な主効果のみならず $(F(1,70)=$ $\left.10.03, p<.01, \eta_{\mathrm{p}}{ }^{2}=.125\right)$, 気づきを伴う行為と気分 導入条件の有意な交互作用が見られた $(F(1,70)=9.93$, $\left.p<.01, \eta_{\mathrm{p}}{ }^{2}=.124\right)$ 。気分導入条件の主効果は, 他の マインドフルネス次元と同様に, 嫌悪導入条件 $(M$ $=19.33, S E M=.84)$ において統制条件 $(M=14.49$, 
Table 2

Mean scores and standard deviation of impersonal moral judgements as functions of mood condition and dispositional mindfulness

\begin{tabular}{lccccccc}
\hline $\begin{array}{l}\text { Mood Induction } \\
\text { FFMQ Substate }\end{array}$ & \multicolumn{3}{c}{ Control } & Disgust & Control & Disgust \\
High & \multicolumn{4}{c}{ Low } \\
\hline Act with aware & $16.10(4.07)$ & $18.00(4.89)$ & $12.93(6.24)$ & $20.55(5.95)$ \\
Nonjudge & $14.83(4.84)$ & $19.16(5.28)$ & $14.75(5.54)$ & $19.48(5.88)$ \\
Nonreactivity & $15.63(4.34)$ & $18.40(6.45)$ & $13.82(6.11)$ & $19.85(5.05)$ \\
Describe & $14.33(4.27)$ & $18.67(4.98)$ & $15.22(6.17)$ & $20.22(6.28)$ \\
Observe & $14.17(5.81)$ & $19.69(4.94)$ & 15.39 & $(4.70)$ & $19.12(5.99)$ \\
\hline
\end{tabular}

Table 3

Mean scores and standard deviation of high-conflict personal moral judgements as functions of mood condition and dispositional mindfulness

\begin{tabular}{|c|c|c|c|c|}
\hline Mood Induction & Control & Disgust & Control & Disgust \\
\hline FFMQ Substate & \multicolumn{2}{|c|}{ High } & \multicolumn{2}{|c|}{ Low } \\
\hline Act with aware & $20.81 \quad(3.96)$ & $20.55(6.64)$ & $14.73(9.07)$ & $22.68(4.10)$ \\
\hline Nonjudge & $19.25(6.62)$ & $21.11(6.04)$ & $17.79(7.48)$ & $22.13(5.09)$ \\
\hline Nonreactivity & $19.58(6.31)$ & $23.13(5.18)$ & $16.82(7.92)$ & $20.85 \quad(5.59)$ \\
\hline Describe & $18.22(8.47)$ & $21.17(5.23)$ & $18.33(8.47)$ & $22.33(5.91)$ \\
\hline Observe & $18.39(7.87)$ & $23.13(4.56)$ & $18.17 （ 6.57 ）$ & $20.77(5.90)$ \\
\hline
\end{tabular}

$S E M=.93 ）$ よりも有意に道徳判断が厳しくなるとい うものだった。交互作用は, Table 3 に見るように, 気づきを伴う行為低群では，嫌悪導入によって有意に 統制条件より道徳判断が厳しくなるのに対し（統制 $M=14.08, S E M=1.66$ vs. 嫌悪 $M=22.93, S E M=$ $1.28)$, 高群では両導入条件の間に有意な差が見られ ないというものだった（統制 $M=20.76, S E M=1.33$ vs. 嫌悪 $M=20.81, S E M=1.36)$ 。気づきを伴う行為 の主効果は有意ではなかった $(F(1,70)=2.34, n s)$ 。

\section{考察}

本研究では, マインドフルネスのどの側面が嫌悪感 情の道徳判断への自動的な波及を防ぐのに関わってい るのかを検討した。まず，嫌悪導入に関して，本研究 では，気づきを伴う行為高群において嫌悪導入の如何 に関わらず，幸福感が高いことが見いだされた。体験 サンプリング法を用いた Killingsworth \& Gilbert （2010）の研究では，心が他の事柄に彷得わず今の活 動に集中していると, 他の事柄に心が彷得っている(マ インドワンダリング）ときと比べて幸福感が高いこと が報告されている。一般的に幸福感が低いと評定され る活動に従事しているときでさえ, 今行っている活動 に集中していれば, そうでないときより幸福感は高い。 本研究における気づきを伴う行為高群において嫌悪導 入の如何に関わらず幸福感が高いという結果は, この ことを反映したものだと考えられる。

道徳判断への影響については，気づきを伴う行為高
群を除いて，導入された生理的な嫌悪感により道徳判 断は厳しくなった。気分導入と道徳判断課題との関係 に気づいた者は分析から除いており, 嫌悪感の道徳判 断課題への波及は自覚を伴わずに生じたと考えられ る。道徳に関わらない判断では嫌悪感の効果が見られ ず，嫌悪感によって判断全般が厳しくなったわけでは ない。これらの結果は, 催眠, 飲み物, 体験想起法, 臭い, 不潔な部屋での実験など，様々な導入法を用い た先行研究と一致し, 導入された生理的な嫌悪感が自 動的に無関連な道徳判断に転移することを示してい る。他方, 気づきを伴う行為高群では, 生理的な嫌悪 感の導入に関わらず，道徳判断は一定していた。この 結果は, 功利主義的な判断に対して感情的な抵抗がよ り大きく，競合を解決するのに統制的処理がより必要 とされる個人的ジレンマ場面でも同様に見られた。こ の結果は，こうした感情的抵抗の大きい場面ですら, 気づきを伴う行為高群は, 導入された嫌悪感により判 断が影響されないことを示している。思考抑制などの 意識的な制御では，こうした認知負荷が高い状況では 嫌悪感によって道徳判断が厳しくなるなどのリバウン ドが起こるはずであるが，非個人的ジレンマ場面同様 に気分の効果はなく，気づきを伴う行為は，思考抑制 などとは異なるプロセスを反映している可能性が示唆 される。

本研究では, 気づきを伴う行為下位尺度のみで嫌悪 感導入後の道徳判断との関連が見られた。この気づき を伴う行為下位尺度は, その 8 項目中 5 項目が 1 因子 
からなる Mindful Attention Awareness Scale (MAAS: Brown \& Ryan, 2003）に由来し, 両者はほぼ同一のマ インドフルネス概念を測定している。この MAASを 用いた研究でも, 低群では, 感情, ゴール, ステレオ タイプ, 死の脅威などによる自動的な判断や行動への 影響が見られるのに対し, 高群では見られないという, 本研究と一致する結果が報告されている（Radel, Sarrazin, Legrain, \& Gobancé, 2009)。本研究では 5 因子 からなるFFMQ を用いることで, MAAS では検討で きなかった気づきを伴う行為以外の側面の効果も検討 した。しかし, 他の側面では嫌悪感の無関連な道徳判 断への波及を食い止められるとする結果は得られな かった。判断しないこと高群では, 排泄物で污れたト イレなどの場面を想起させても，実験終了時点での嫌 悪感の上昇は見られなかったが, それでも嫌悪感の無 関連な道徳判断への転移は見られた。本研究の結果は, 感情体験を受容したり（判断しないこと），言葉で表 現したり (描写), 感情体験に距離を置く（反応しな いこと）だけでは感情の無関連な判断への転移を防ぐ には十分ではなく，それを防ぐには，その瞬間瞬間の 行動に十分な注意を向ける（気づきを伴う行為）必要 があることを示唆する1。気づきを伴う行為高群では, 今ここでの課題である道徳判断課題に十分な注意を向 けることができたために，現行の課題とは無関連な先 に導入された嫌悪感の影響を受けなかったのではない かと考えられる。

本研究の結果はまた, 注意の集中・切り替えなどの 注意の実行機能が優れた個人は，その優れた感情調整 機能を通して感情の判断への自動的な転移を防ぎうる ことを示すものと解釈することも可能である。マイン ドフルネス瞑想が注意の実行機能を向上させること は, 脳画像研究, 行動デー夕の双方において示されて いるが (Farb, Segal, Mayberg, Bean, McKeon, Fatima, \& Anderson, 2007; Tang, Ma, Wang, Fan, Feng, Lu, Yu, Sui, Rothbart, Fan, \& Posner, 2007), 本研究の限りでは, 本 結果が, マインドフルネスの直接の効果なのか, マイ ンドフルネスと関連の深い実行機能を通しての効果な のかは判断できない。今後の検討が必要である。

本研究の最大の限界は, （調査対象として）その多 くが瞑想経験のない学生サンプルを用いていることで ある。こうした学生サンプルでは観察因子が抑うつ・ 不安などの心理的症状と正の相関を持つのに対し，賏 想の熟練者では同因子が抑うつ・不安などの心理的症 状と負の相関, 心理的な幸福と正の相関になるなど, 瞑想経験によって観察因子の症状や幸福との関係が変

観察の効果が見られなかった理由は, 後に論じるように, 本研究の対象者の大半が瞑想未経験者であったためと考えられ る。
化することが報告されている（Baer, Smith, Lykins, Button, Krietemeyer, Sauer, Walsh, Duggan, \& Williams, 2008）。したがって，感情の自動的転移の抑止に関わ る因子についても, マインドフルネス瞑想の深化に応 じて変わる可能性がある。今後, 瞑想の熟達者を対象 とした検討が必要である。また，本研究は嫌悪感の道 徳判断への効果を調べた先行研究と同様のパラダイム を用いており, 功利主義的判断に要する反応時間を測 定していない。気づきを伴う行為高群において, 反応 時間が個人的ジレンマ場面においても気分導入条件で 変化がないことを示すことができれば，抑制などの意 識的な制御が行われた場合との違いをより明確に示せ ると考えられる。さらに，本研究は個人差を扱ったも のであり，他の潜在的な介在因子の関与を排除できな い。今後, マインドフルネス瞑想によって時には偏見 や差別にもつながりかねない感情の判断への自動的な 転移を防ぎ得るか, 介入研究が必要である。

\section{引用文献}

Baer, R. A., Smith, G. T., Hopkins, J., Krietemeyer, J., \& Toney, L. (2006). Using self-report assessment methods to explore facets of mindfulness. Assessment, 13, $27-45$.

Baer, R. A., Smith, G. T., Lykins, E., Button, D., Krietemeyer, J., Sauer, S., Walsh, E., Duggan, D., \& Williams, J. M. (2008). Construct validity of the five facet mindfulness questionnaire in meditating and nonmeditating samples. Assessment, 15, 329-342.

Brown, K. W., \& Ryan, R. M. (2003). The benefits of being present: Mindfulness and its role in psychological well-being. Journal of Personality and Social Psychology, 84, 822-848.

Clore, G., \& Huntsinger, J. R. (2007). How emotions inform judgment and regulate thought. Trends in Cognitive Sciences, 9, 393-399.

Damasio, A. (1994). Descartes' error: Emotion, reason, and the human brain. New York: Putnam.

DeWall, C.N., Baumeister, R.F., Stillman, T., \& Gailliot, M.T. (2007). Violence restrained: Effects of self-regulation and its depletion on aggression. Journal of Experimental Social Psychology, 43, 62-76.

Eskine, K. J., Kacinik, N. A., \& Prinz, J. J. (2011). A bad taste in the mouth: Gustatory disgust influences moral judgments. Psychological Science, 22, 295-299.

Farb, N. A., Segal, Z. V., Mayberg, H., Bean, J., McKeon, D., Fatima, Z., \& Anderson, A. K. (2007). Attending to the present: Mindfulness meditation reveals distinct neural modes of self-reference. Social Cognitive and Affective Neuroscience, 2, 313-322.

Greene, J. D., Morelli, S. A., Lowenberg, K., Nystrom, L. E., \& Cohen, J. D. (2008). Cognitive load selectively interferes with utilitarian moral judgment. Cognition, 107, 1144-1154.

Greene, J. D., Nystrom, L. E., Engell, A. D., Darley, J. M., 
\& Cohen, J. D. (2004). The neural bases of cognitive conflict and control in moral judgment. Neuron, 44 389-400.

Greene, J. D., Sommerville, R. B., Nystrom, L. E., Darley, J. M., \& Cohen, J. D. (2001). An fMRI investigation of emotional engagement in moral judgment. Science, 293, 2105-2108.

Haidt, J. (2001). The emotional dog and its rational tail: A social intuitionist approach to moral judgment. Psychological Review, 108, 814-834.

Inbar, Y., Pizarro, D. A., \& Bloom, P. (2012). Disgusting smells cause decreased liking of gay men. Emotion, 12, 23-27.

Kabat-Zinn, J. (1990). Full catastrophe living: Using the wisdom of your body and mind to face stress, pain and illness. NewYork: Delacourt. （カバットジン，J．春木 豊（訳）（2007）。 マイン ドフルネスストレス低減法 北大路書房)

Killingsworth, M. A., \& Gilbert, D. T. (2010). A wandering mind is an unhappy mind. Science, 330, 932.

Kohlberg, L. (1969). Stage and sequence: The cognitivedevelopmental approach to socialization. In D. A. Goslin (Ed.), Handbook of socialization theory and research. Chicago: Rand McNally. pp. 347-480.

Macrae, C. N., Bodenhausen, G. V., Milne, A. B., \& Jetten, J. (1994). Out of mind but back in sight: Stereotypes on the rebound. Journal of Personality and Social Psychology, 67, 808-817.

Radel, R., Sarrazin, P., Legrain, P., \& Gobancé, L. (2009).
Subliminal priming of motivational orientation in educational settings: Effect on academic performance moderated by mindfulness. Journal of Research in Personality, 43, 695-698.

Schnall, S., Benton, J., \& Harvey, S. (2008). With a clean conscience: Cleanliness reduces the severity of moral judgments. Psychological Science, 19, 1219-1222.

Schnall, S., Haidt, J., Clore, G.L., \& Jordan, A. H. (2008). Disgust as embodied moral judgment. Personality and Social Psychology Bulletin, 34, 1096-1109.

Schwarz, N., \& Clore, G. L. (1983). Mood, misattribution, and judgments of well-being: Informative and directive functions of affective states. Journal of Personality and Social Psychology, 45, 513-523.

Sugiura, Y., Sato, A., Ito, Y., \& Murakami, H. (2012). Development and validation of the Japanese version of the Five Facet Mindfulness Questionnaire. Mindfulness, 3, 85-94.

Tang, Y. Y., Ma, Y., Wang, J., Fan, Y., Feng, S., Lu, Q., Yu, Q., Sui, D., Rothbart, M. K., Fan, M., \& Posner, M. I. (2007). Short term meditation training improves attention and self regulation. Proceedings of the National Academy of Sciences, USA, 104, 17152-17156.

Wheatley, T., \& Haidt, J. (2005). Hypnotically induced disgust makes moral judgments more severe. Psychological Science, 16, 780-784.

- 2012.10.2 受稿, 2013. 7.6 受理—— 